\title{
BASIC TECHNICAL ELEMENTS IN INLINE SPEED SKATING
}

\author{
Anna Yugay
}

\begin{abstract}
Резюме. Швидкісний біг на роликових ковзанах - циклічний вид спорту, для якого важливо мати високі функціональні показники. Однак техніка - не менш важливий елемент підготовки спортсменів високого класу. Через схожі біомеханічні характеристики техніку швидкісного бігу на роликових ковзанах часто плутають зі швидкісним бігом на ковзанах. Однак це принципово два різних види спорту зі своїми технічними особливостями та змагальною діяльністю. Метою нашої роботи є вивчення особливостей техніки в даному виді спорту, їі основних елементів, які постійно використовуються спортсменами на змаганнях.
\end{abstract}

Ключові слова: швидкісний біг на роликових ковзанах, подвійне відштовхування, схресний крок, випад.

Резюме. Скоростной бег на роликовых коньках - циклический вид спорта, для которого важны многие фрункциональные показатели. Однако техника - не менее важный элемент подготовки спортсменов высокого класса. Из-за схожих биомеханических характеристик технику скоростного бега на роликах часто путают со скоростным бегом на коньках. Но это принципиально два разных вида спорта со своими техническими особенностями и соревновательной деятельностью. Целью нашого исследования является изучение особенностей техники в данном виде спорта, ее основных элементов, которые постоянно используются спортсменами на соревнованиях.

Ключевые слова: скоростной бег на роликовых коньках, двойной толчок, скрестный шаг, выпад.

\section{Formulation of Problem}

Unfortunately, we have not found enough information in the literature concerning the theory and methodology of training athletes in speed races on roller skates, including research into the technical and tactical training athletes. All the training tools and methods are taken from related species: skating and cycling, skiing, etc. It was also used knowledge gained from own competition experience, other athletes during communication. At the same time, we know that rational training process can only be done by optimizing strictly on scientific basis. We are familiar with some literature, which gave us an idea of technical training in their sport.

Link with Academic Programs or Practical Tasks. The thesis is performed as part of a research topic 2.12. «The formation of a multi-selection and orientation of athletes», according to the Consolidated Plan research in the field of physical culture and sports in 2011-2015 and thematic plan approved by the Ministry of Education, Youth and Sports of Ukraine.

Aim of Research - study technique elements, more frequently used in competition of high-class athletes.

Methods of Research: theoretical analysis and synthesis of scientific, methodical and professional literature.

Results and Discussion

Inline skating requires a balance of agility, power, speed, endurance and coordination. It is very similar to ice skating. Research of ice skating and inline skating shows that there are no significant differences in performance when referring to oxygen uptake, ventilation, or heart rate. The stroke frequency, work per stroke, and power have also been shown to be the same. One of the major differences between ice and inline skating is the amount of friction between the skates and the surface. The wheels create much more friction on land than blades do on ice; for this reason it is believed that $45 \%$ of the power created by the inline skater is lost to friction $[1,5]$.

When it comes to biomechanical characteristics inline skating is a unique activity. Unlike traditional weight bearing sports, inline skating does not have the up and down motion of the center of gravity. Rather, it has a horizontal displacement of the center of gravity that results in locomotion. Inline skating primarily uses the musculature of the lower body for locomotion. Running and cycling uses some of the same muscles, but in a different manner. These activities primarily use those muscles to flex and extend the hip, knee, and ankle joints. Inline skating uses these muscles in this fashion to some extent, but also uses the abductors and adductors of the hip.

These muscle groups move the leg away from and towards the midline of the body. Both of these muscle groups aid in lateral movement. Very few aerobic exercises offer the lateral musculature training that inline skating does [1, 5, 7]. This training and development of the hip muscles does not occur 
during traditional cardiovascular activities. The thigh and gluteal muscles are also developed due to the lower limb positioning during the glide phase. The bent over stance used during speedskating also strengthens the low back. This bent over stance is similar to a cyclists, but there are no handle bars to support the weight of the trunk. There is also no seat to support the weight of the body, which makes the lower limbs and lower body musculature support the entire body weight. Another important benefit of inline skating is the repetitive glide of the movement. During running there is a great deal of stress that is placed on the lower joints to absorb the pounding of the foot into the pavement. With inline skating the joint stress is reduced. This makes it physical demanding but the athlete recovers from the workout quicker and without constant abuse on the joints. Research has shown that inline skating offers similar cardiovascular benefits when compared to running or cycling. Because of these advantages many people use inline skating as a method of crosstraining [7].

Inline skating be used to train either the aerobic or anaerobic energy system. The energy system used depends upon the type of skating the athlete is performing.

Short, quick bursts are supplied mainly by the anaerobic energy system. Long, sustained efforts use the aerobic energy system. Depending on the sport, the athlete can fine tune the workout to primarily use one system or the other. A distance runner or triathlete would want to focus on the aerobic energy system. A football player would want to focus on the anaerobic. Some athletes use inline skating training as a recovery type workout which keeps the stress off of the joints while still improving fitness. Inline skating can be used in a variety of ways to improve sports performance, cardiovascular endurance, and add variety to training $[5,7,8]$.

We found the most common technical elements are: double-push, crossover steps, lunge.

The double-push technique is main technique of skating. It involves two pushes instead of one. Although both actions are not pushes by definition, this technique allows a skater to apply external power in two ways. As in classic technique, power is applied during the normal pushing phase of the movement. The double-push is superior because supplementary propulsive force is applied during what is normally a static glide period [1, 3, 6, 9].

Part of what makes the double-push a difficult technique to describe is the fact that the typical classic technique stages of push, glide, and recovery involve more overlap. During the double-push, there is much more going on simultaneously. A description of the double-push is further complicated by the fact that traditional terms such as «glide leg» take on new meaning because the glide leg is supporting the body and pulling inward toward the body. Because of this, the «glide leg» is hereby referred to as the pulling/ support leg. Regardless of the increased complexity of this technique, a similar process of phasic breakdown is valuable for analyzing the movement pattern. However, it must be remembered that these are not stages that follow in discrete and independent sequence, but simultaneous actions which form a complex pattern of movement. The double-push is best described using the following phases:

- Push;

- Set-Down;

- Pull (i.e., Glide);

- Recovery.

With the double-push, the sideward extension of the push leg progresses in much the same manner as it does with conventional technique. However, the pulling motion of the support leg during the glide results in a push that is initiated from a more inward position (i.e., closer to or across the midline of the body). This constitutes one of the main advantages of the double-push technique: starting the push from this more inward position effectively maximizes one's push displacement without necessitating a painfully low knee bend. This may sound confusing at first, and this is one of the problems inherent in discussing the technique. Since double-push becomes so complex when diluted into mere words, it is difficult to ascribe a logical starting point to begin the discussion [1, 2, 4].

After many years of trying to learn the doublepush, perfect it, and then teach it to others, it has become apparent that one of the most difficult related skills to acquire is the set-down of the recovery skate. Classic technique involves setting the recovery skate down almost immediately beside and slightly ahead of the support leg skate as the weight transfer occurs [4].

With the double-push technique, the set-down is slightly delayed, and occurs significantly more to the outside of the body. This component of the movement pattern is so important that the remaining chain of events simply cannot be performed if the set-down is incorrect. Grasping the basic premise of the set-down mechanics is a first step, but applying it is an entirely different and more difficult matter. For this reason, a considerable amount of attention and illustration is dedicated to this phase of the double-push stride.

The pulling/support leg has reached the farthest point under the midline of the body. Notice that at this point the wheels roll on the outside edge. The free recovery skate is in the final stages of regrouping behind the support leg.

The support leg skate begins to track outward in the early stages of push, yet the wheels have not yet rolled onto the inside edge. 
Picture 1 - Force output in classic vs. double-push technique. In classic technique, only one moment of force $\left(F_{1}\right)$ is applied. The double-push allows a skater to apply propulsive force at two separate times $\left(F_{1}\right.$ and $\left.F_{2}\right)$.

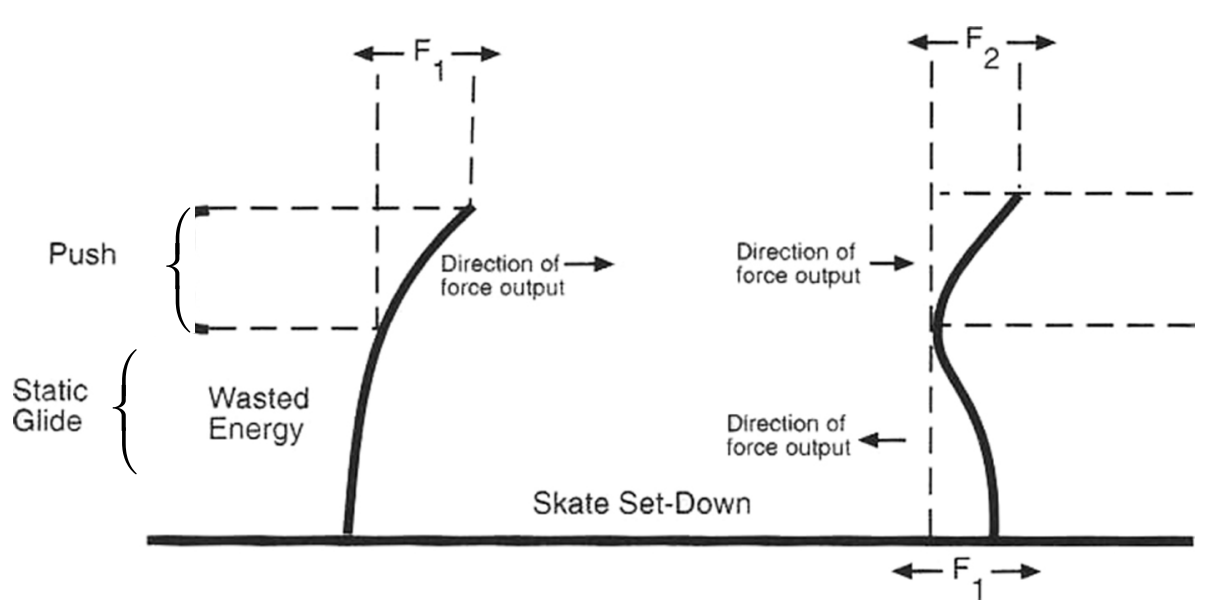

As opposed to the circle-around-the-back path of clas before we delve into this component of the double-push movement pattern, it is important to note that the recovery of the pushing leg occurs simultaneously with the inward pulling action of the support leg. Overall, the recovery complements the pulling action of the support leg by facilitating balance, stabilizing the hips, and helping to optimize force generation. From a more practical standpoint, this process serves to set up the recovery skate for the next set-down and subsequent pulling action [6, 8].

In-line skater decelerates much faster that an ice skater, minimizing glide time (and having a faster stride frequency), is therefore advantageous. The snap recovery promotes a faster stroke cadence and more closely matches the coordination of the pulling support leg [5].

The great superiority of the double-push is that by using it, positive work can be performed during what is normally a static, energy-inefficient glide phase. The pulling of the inner thigh muscles leverages the outside wheels' edge to help generate propulsion, much as the lateral push produces forward motion using the inside wheels' edge. As a result, the doublepush allows a skater to do more total work per stride cycle than does classic technique. One might think that the push-pull method would require twice the energy compared with the «single-push» of classic skating. It does not. The double-push simply makes constructive use of the available, contractile glide energy by using it for additional propulsion.

One of the best ways to go fast is to increase push displacement (i.e., the distance the skate travels sideways from the beginning to the end of the push). With classic technique, the only way to achieve a longer push displacement is to bend the knees (squat lower). Research shows, however, that such deep knee flexion increases the level of isometric tension in the quadriceps muscles. This tension is a major limiting factor in performance: it temporarily restricts blood flow in the muscles, resulting in a more rapid accumulation of metabolic substances (such as lactic acid) that interfere with the function of the muscle fibers. Deep knee flexion represents a classic catch-22 situation: sitting low is required to achieve a long push, but doing so is taxing and can cause the early onset of local muscle fatigue. The double-push doesn't entirely solve this problem, but it lessens it. See picture 1.

Allowing the support leg to come under the body and across the midline during the pulling part of the glide allows the push to be initiated from a more inward position. Given the same preextension (preparatory) knee angle, the total push displacement will be increased. Compared with a skater using classic technique, a double-push skater can either sit higher while equaling the push displacement of the classic skater-or can assume the same low knee bend of the classic skater and reach a greater push displacement. Either way, increased mechanical efficiency results, without claim to additional physiologic processes. Instead, a subjective feeling of enormous power results from the noticeable decrease of lactic acid in the muscles $[1,5,9]$.

Up to 80 percent of an in-line race may be covered with both arms placed on the back. Often, however, a single- or double-arm swing is more appropriate. Swinging the arms aids balance, maintains tempo, and increases the power applied through the legs during push-off. To work effectively, the arm swing must precisely counter the motion of the legs $[1,3,4]$.

Crossover steps allow a skater to take the shortest route through a corner, counteract the centrifugal force that pushes the body away from the center of the curve, and build speed and acceleration through a turn. Crossover steps allow each skate to apply force toward the outside of the turn by recovering the outer skate in front of the inner. Some might argue that mastery of crossover steps is a relatively low priority for an outdoor in-line skater. It's true 
that some courses are so straight that crossovers may not even be necessary. Most road courses do have corners, however, that would be most effectively negotiated using crossover technique. Consequently, skaters who have developed their ability in this area have an enormous advantage over those who have not $[6,7]$.

Successful skaters must be proficient at turning both ways, which makes in-line racing interesting. Gaining this proficiency requires practice time and versatility in technique. Many racers prefer lefthand turns, because the counterclockwise direction is the direction of rotation for track skating. On the other hand, many racecourses have several righthand turns as well.

The mechanics of good turn technique on in-line skates are essentially identical to those on ice skates. A detailed breakdown of upper- and lower-body position for ice speedskating, as well as crossover arm-swing mechanics. Regardless of the similarities in technique between ice and in-line, significant differences also exist between them. This short section discusses these discrepancies and focuses on specific crossover issues as they relate to in-line speedskating $[2,8]$.

The lunge technique is difficult to execute, and only the best skaters will be able to perform this technique at sprint speed. The most difficult lunge involves projecting the front skate forward on the rear wheel while the rear skate balances on the toe wheel, somewhat like the slits. An easier version of the lunge involves keeping the front thrusting skate flat, while the skate of the rear leg balances on its toe wheel. Overall, the lunge is superior to the jab because it allows a skater to extend one skate significantly more forward, and a skater using this technique can expect to beat a competitor who is using the jab. Performing a lunge at high speeds, however, requires exceptional strengths, flexibility and stability [1,6].

The Conclusions and Perspectives for Further Research on this Direction:

We found the most common technical elements are: double-push, crossover steps, lunge. The doublepush technique is main technique of skating. It involves two pushes instead of one. The double-push is best described using the following phases: push, set-down, pull (i.e., Glide), recovery. Crossover steps allow a skater to take the shortest route through a corner, counteract the centrifugal force that pushes the body away from the center of the curve, and build speed and acceleration through a turn. The lunge technique is difficult to execute, and only the best skaters will be able to perform this technique at sprint speed.

We plan to study how skillfully own skating technique Ukrainian skaters and the best skaters in the world, in the future.

\section{References}

1. Barry Publow. Speed on skates (a complete technique, training, and racing guide for in-line and ice skaters) I Publow Barry. - United States of America: Human Kinetics, 1999. - 343 p.

2. Dakota Stevens. A guide to roller skating including artistic roller skating, roller hockey, inline skating, and more/ Stevens Dakota. - United States of America, 2011. - $96 \mathrm{p}$.

3. Dianne Holum. The complete handbook of speed skating / Holum Dianne. - United States of America: Enslow Pub Inc, 1984. - 256 p.

4. Miller Liz. Advanced in-line skating / Liz Miller. - Plymouth: Ragged Mountain Press, 2000. - 150 p.

5. Physiological and biomechanical comparison of roller skating and speed skating on ice / [de Boer. R. W., Vos E., Hutter W., de Groot G., van Ingen Schenau G. J.]. - Amsterdam: Free university, 1987. - 8 p.

6. Powell Mark. In-line skating/ Mark Powell, John Svensson. - United States of America: Human Kinetics, 1998. - $191 \mathrm{p}$.

7. R. Burke. Precision heart rate training. For maximum fitness and performance / Burke R. - Champaign, IL.: Human Kinetics, 1998, -211 p.

8. Ruud $H$. Koning. Home advantage in speed skating: Evidence from Individual data. - Groninger: SOM Research Report 03F38, 2008. - 22 p.

9. Lugea Carlos. Algunas consideraciones sobre biomecanica, tecnica y el modelo tecnico en el patinaje de velocidad / Carlos Lugea. - Madrid: Universidad autonoma de Madrid, 2009. - 66 p. 